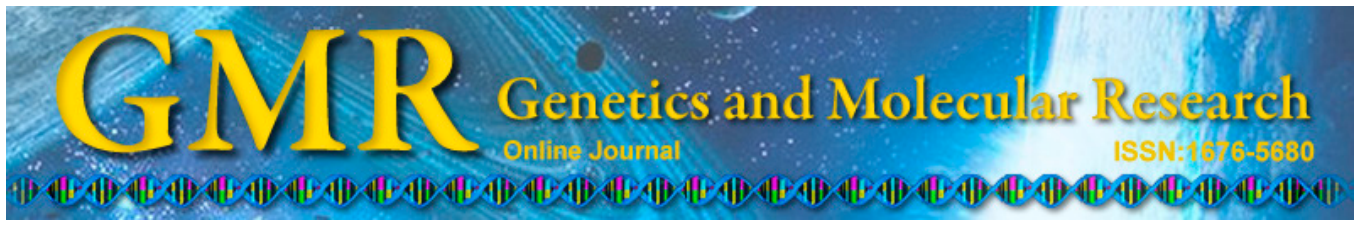

Short Communication

\title{
New loci of Lychnophora ericoides and transferability to Lychnophora pinaster, endangered medicinal species from Brazil
}

M.A.R. Vieira', M.O.M. Marques ${ }^{2}$, L.L. Haber ${ }^{3}$, B.B.Z. Vigna ${ }^{4}$, M.M. Bajay ${ }^{5}$, J.B. Pinheiro ${ }^{5}$, A.P. Souza ${ }^{6}$, J. Semir ${ }^{7}$ and M.I. Zucchi ${ }^{8}$

${ }^{1}$ Departamento de Produção Vegetal/Horticultura, Faculdade de Ciências Agronômicas, Universidade Estadual Paulista, Botucatu, SP, Brasil

${ }^{2}$ Centro de Pesquisa e Desenvolvimento de Recursos Genéticos Vegetais, Instituto Agronômico, Campinas, SP, Brasil

${ }^{3}$ Embrapa Hortaliças, Brasília, DF, Brasil

${ }^{4}$ Embrapa Pecuária Sudeste, São Carlos, SP, Brasil

${ }^{5}$ Departamento de Genética e Melhoramento de Plantas, Escola Superior de Agricultura "Luiz de Queiroz",

Universidade de São Paulo, Piracicaba, SP, Brasil

${ }^{6}$ Centro de Biologia Molecular e Engenharia Genética, Universidade Estadual de Campinas, Campinas, SP, Brasil

${ }^{7}$ Departamento de Botânica, Instituto de Biologia, Universidade Estadual de Campinas, Campinas, SP, Brasil

${ }^{8}$ Agência Paulista de Tecnologia dos Agronegócios, Pólo Centro Sul, Piracicaba, SP, Brasil

Corresponding author: M.I. Zucchi

E-mail: mizucchi@apta.sp.gov.br

Genet. Mol. Res. 13 (4): 10878-10882 (2014)

Received January 8, 2014

Accepted June 11, 2014

Published December 19, 2014

DOI http://dx.doi.org/10.4238/2014.December.19.8

ABSTRACT. Lychnophora ericoides and Lychnophora pinaster are species used in popular medicine as analgesic or anti-inflammatory 
agents to treat contusions, rheumatism, and insect bites. In this study, 21 simple sequence repeat loci of $L$. ericoides were developed and transferred to $L$. pinaster. Three populations of $L$. ericoides and 2 populations of $L$. pinaster were evaluated; they were collected in the State of Minas Gerais. Population parameters were estimated, and the mean values of observed and expected heterozygosity were 0.297 and 0.408 (L. ericoides) and 0.228 and 0.310 (L. pinaster), respectively. Greater genetic variability was observed within populations than between populations of L. ericoides (62 and 37\%) and L. pinaster (97 and $2.8 \%$ ). These results provide information for genetic conservation and taxonomic studies of these endangered species.

Key words: Microsatellite; Population genetics; Arnica; Medicinal plant

\section{INTRODUCTION}

Several species of the genus Lychnophora (Asteraceae) have aromatic and medicinal potential and are found in rock sites in the Brazilian states of Minas Gerais, Bahia, Goiás, and Distrito Federal (Semir et al., 2011). Predatory collection associated with the restricted distribution of the habitat, which includes small and isolated populations, has contributed to the decline of natural populations of the genus Lychnophora. The species Lychnophora pinaster Mart. and Lychnophora ericoides Mart. are on the list of endangered species of the State of Minas Gerais (COPAM, 2000), and the latter species is also on the list of endangered plants of IBAMA (IBAMA, 2008), highlighting the need to understand the ecology of these species and the contribution of new techniques to their preservation.

L. ericoides, which is popularly known as arnica or false arnica, occurs in the states of Minas Gerais, Goiás, and Distrito Federal. L. pinaster, which is known as arnica, is found in the State of Minas Gerais. The 2 species are very close, and the taxonomic separation between them is very complicated (Semir et al., 2011). The species are used in popular medicine as alcoholic extracts, such as anti-inflammatory, anesthetic, and scarring agents (dos Santos et al., 2005; Silveira et al., 2005).

\section{MATERIAL AND METHODS}

Total genomic DNA was extracted from freeze-dried leaves of $L$. ericoides using the cetyltrimethylammonium bromide protocol described by Doyle and Doyle (1990) with modifications. A library enriched in microsatellite regions was obtained through protocols adapted from Billotte et al. (1999). The total DNA of a genotype of L. ericoides was digested by the enzyme $A f a \mathrm{I}$ (Invitrogen, CA, USA) and enriched with fragments using probes with the motifs $(\mathrm{CT})_{8}$ and $(\mathrm{GT})_{8}$. The amplified fragments were cloned in the pGEM-T Easy Vector System (Promega, Madison, WI, USA) according to the protocol provided with the plasmid vector and transformed in XL1-Blue competent cells. Positive clones were selected using the $\beta$-galactosidase gene and kept overnight with ampicillin.

The sequencing reaction was performed with $2 \mu \mathrm{L}$ Save Money buffer $\left(5 \mathrm{mM} \mathrm{MgCl}_{2}\right.$, 200 mM Tris-HCl, pH 9), 5 pM SP6 initiator (5'-CATACGATTTAGGTGACACTATAG-3'), 2 $\mu \mathrm{L}$ plasmid extraction, and $0.4 \mu \mathrm{L}$ BigDye Terminator v3.1 (Applied Biosystems, CA, USA) 
M.A.R. Vieira et al.

10880

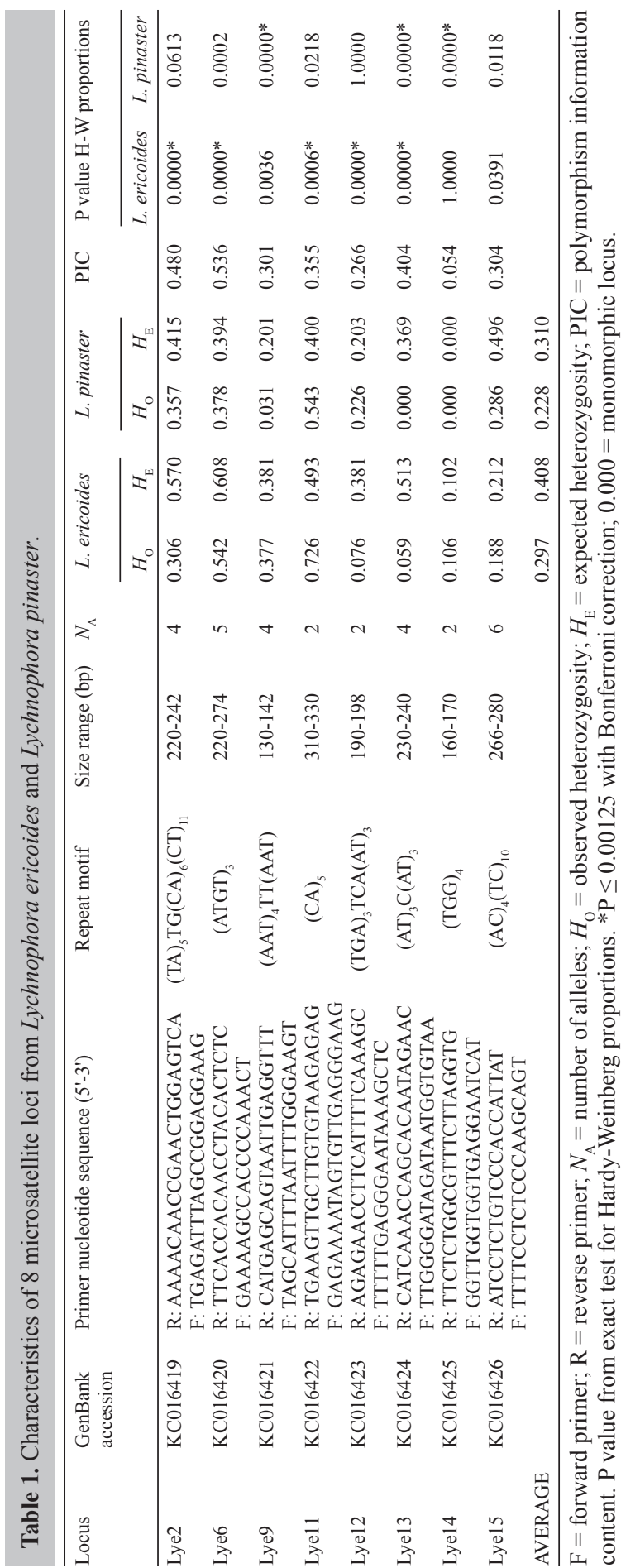

Genetics and Molecular Research 13 (4): 10878-10882 (2014)

CFUNPEC-RP www.funpecrp.com.br 
in a final volume of $10 \mu \mathrm{L}$. The sequencing reactions were performed in a thermocycler (MJ Research, BioRad, Hercules, California, USA), under the following conditions: $96^{\circ} \mathrm{C}$ for 2 min; 26 cycles at $96^{\circ} \mathrm{C}$ for $45 \mathrm{~s}, 50^{\circ} \mathrm{C}$ for $30 \mathrm{~s}$, and $60^{\circ} \mathrm{C}$ for $4 \mathrm{~min}$. Polymerase chain reaction products were precipitated in isopropanol (65\%), centrifuged, and washed with $70 \%$ alcohol. Ninety-six positive clones were sequenced in an ABI 3700 automatic sequencer (Applied Biosystems, CA, USA).

In total, 21 pairs of primers were designed using the Primer 3 v 0.4 .0 software (Rozen and Skaletsky, 2000). The loci were assessed in 3 populations of $L$. ericoides and transferred to 2 populations of $L$. pinaster, which were both collected in the state of Minas Gerais, Brazil. Eight loci amplified well from the populations of $L$. ericoides, and 6 loci amplified well from the populations of $L$. pinaster. These loci were polymorphic and informative. The reactions included $1 \mathrm{ng}$ DNA, $0.4 \mathrm{mM}$ each primer, $0.2 \mathrm{mM}$ dNTPs, and $2 \mathrm{mM} \mathrm{MgCl}_{2}$. The amplification conditions were as follows: $94^{\circ} \mathrm{C}$ for $2 \mathrm{~min} ; 40$ cycles of $94^{\circ} \mathrm{C}$ for $1 \mathrm{~min}, 56^{\circ} \mathrm{C}$ for $1 \mathrm{~min}$, and $72^{\circ} \mathrm{C}$ for $1 \mathrm{~min}$; and extension at $72^{\circ} \mathrm{C}$ for $10 \mathrm{~min}$. The amplification products were separated by electrophoresis on $7 \%$ denaturing polyacrylamide gels and viewed by silver staining (Creste et al., 2001).

The adherence test (Fisher's exact test) for the balance proportions of Hardy-Weinberg was determined using the GenePop software (Raymond and Rousset, 1995). The allelic frequencies, the number of alleles per locus, the observed $\left(H_{\mathrm{O}}\right)$ and expected heterozygosity $\left(H_{\mathrm{E}}\right)$, and the polymorphic content were calculated using the MSTOOLS software (Park, 2008) (Table 1). Wright's F-statistics were estimated using the GDA software (Lewis and Zaykin, 2001), and the analysis of molecular variance was performed between and within populations using the Arlequin software (Schneider et al., 2007).

\section{RESULTS AND DISCUSSION}

The average $H_{\mathrm{O}}$ was smaller than the average $H_{\mathrm{E}}, 0.297$ and 0.408 (L. ericoides) and 0.228 and 0.310 (L. pinaster), respectively (Table 1). Rabelo et al. (2011) found that the $H_{\mathrm{O}}$ (0.828) was greater than the $H_{\mathrm{E}}(0.797)$ when they analyzed natural populations of $L$. ericoides. For the species L. pinaster, Haber et al. (2009) found that the $H_{\mathrm{O}}$ was smaller than the $H_{\mathrm{E}}$ in the Antena ( 0.481 and 0.574$)$ and Estrada Real (0.563 and 0.625) populations.

Greater genetic variability was observed within populations than between the populations of L. ericoides (62 and 37\%) and L. pinaster (97 and 2.85\%). The data obtained in this study showed a high variability between populations of $L$. ericoides, indicating that it is necessary to sample a large number of individuals in each population and to collect various populations to ensure the maintenance and conservation of this species. The low genetic variability found among populations of $L$. pinaster may be related to the geographical proximity among them, which allows high gene flow.

We may conclude that microsatellite markers for these species may be used in the creation of a germplasm database and contribute to the conservation, genetic diversity, and taxonomic studies of these endangered medicinal species.

\section{REFERENCES}

Billotte N, Lagoda PJR, Risterucci AM and Baurens FC (1999). Microsatellite-enriched libraries: applied methodology for the development of SSR markers in tropical crops. Fruits 54: 277-288. 
COPAM, Conselho de Política Ambiental (2000). Lista das Espécies Ameaçadas de Extinção da Flora do Estado de Minas Gerais. Available at [http//www.biodiversitas.org.br/florabr/MG-especies-ameacadas.pdf]. Accessed November 8, 2009.

Creste S, Tulmann Neto A and Figueira A (2001). Detection of simple sequence repeat polymorphisms in denaturing polyacrylamide sequencing gels by silver staining. Plant Mol. Biol. Rep. 19: 299-306.

dos Santos MD, Gobbo-Neto L, Albarella L, de Souza GE, et al. (2005). Analgesic activity of di-caffeoylquinic acids from roots of Lychnophora ericoides (Arnica da serra). J. Ethnopharmacol. 96: 545-549.

Doyle JJ and Doyle JL (1990). Isolation of plant DNA from fresh tissue. Focus 12: 13-15.

Haber LH, Cavallari MM, Santos FR, Marques MO, et al. (2009). Development and characterization of microsatellite markers for Lychnophora pinaster: a study for the conservation of a native medicinal plant. Mol. Ecol. Resour. 9: 811-814.

IBAMA (Instituto Brasileiro do Meio Ambiente e dos Recursos Naturais Renováveis) (2008). Lista Oficial de Espécies Brasileiras Ameaçadas de Extinção. Available at [http://www. ibama.gov.br/documentos/lista-de-especiesameacadas-de-extincao]. Accessed October 8, 2008.

Lewis PO and Zaykin D (2001). Genetic Data Analysis: computer program for the analysis of allelic data. Version 1.0. Available at [http://hydrodictyon.eeb.uconn.edu/people/plewis/software.php]. Accessed November 21, 2010.

Park SDE (2008). MStools v 3.1.1: Excel Spreadsheet Toolkit for Data Conversion. Available at [http://animalgenomics. ucd.ie/sdepark/ms-toolkit/]. Accessed November 21, 2010.

Rabelo SG, Teixeira CF, Telles MPC and Collevatti RG (2011). Development and characterization of microsatellite markers for Lychnophora ericoides, an endangered Cerrado shrub species. Conserv. Genet. Resour. 3: 741-743.

Raymond M and Rousset F (1995). GENEPOP (version 1.2). population genetics software for exact tests and ecumenism. J. Hered. 86: 248-249.

Rozen S and Skaletsky HJ (2000). Primer3: bioinformatics methods and protocols. In: Methods in molecular biology (Krawetz S and Misener S, eds.). Humana Press, New York, 365-386.

Schneider S, Roessli D and Excoffier L (2007). ARLEQUIN ver.3.11: a software for population genetic data analysis. Genetics and Biometry Laboratory, University of Geneva, Geneva.

Semir J, Rezende AR, Monge M and Lopes NP (2011). As Arnicas Endêmicas das Serras do Brasil: Uma Visão Sobre a Biologia e a Química das Espécies de Lychnophora (Asteraceae). UFOP, Ouro Preto, 212.

Silveira D, Wagner H, Chiari E, Lombardi JA, et al. (2005). Biological activity of the aqueous extract of Lychnophora pinaster Mart. Rev. Bras. Farmacogn. 5: 294-297. 